\title{
Prevalence of asthma and risk factors for asthma-like symptoms in Aboriginal and non-Aboriginal children in the northern territories of Canada
}

\author{
Zhiwei Gao MD MSc ${ }^{1}$, Brian H Rowe MD FCCP ${ }^{2}$, Carina Majaesic MD FRCPC ${ }^{3}$, \\ Cindy O'Hara RN CAE ${ }^{4}$, A Senthilselvan MSc PhD ${ }^{1}$
}

Z Gao, BH Rowe, C Majaesic, C O'Hara, A Senthilselvan. Prevalence of asthma and risk factors for asthma-like symptoms in Aboriginal and non-Aboriginal children in the northern territories of Canada. Can Respir J 2008;15(3):139-145.

BACKGROUND: Few studies have investigated the prevalence and risk factors of asthma in Canadian Aboriginal children.

OBJECTIVE: To determine the prevalence of asthma and asthmalike symptoms, as well as the risk factors for asthma-like symptoms, in Aboriginal and non-Aboriginal children living in the northern territories of Canada.

METHODS: Data on 2404 children, aged between 0 and 11 years, who participated in the North component of the National Longitudinal Survey of Children and Youth were used in the present study. A child was considered to have an asthma-like symptom if there was a report of ever having had asthma, asthma attacks or wheeze in the past 12 months.

RESULTS: After excluding 59 children with missing information about race, 1399 children (59.7\%) were of Aboriginal ancestry. The prevalence of asthma was significantly lower $(\mathrm{P}<0.05)$ in Aboriginal children $(5.7 \%)$ than non-Aboriginal children (10.0\%), while the prevalence of wheeze was similar between Aboriginal (15.0\%) and non-Aboriginal $(14.5 \%)$ children. In Aboriginal children, infants and toddlers had a significantly greater prevalence of asthma-like symptoms $(30.0 \%)$ than preschool-aged children $(21.5 \%)$ and school-aged children (11.5\%). Childhood allergy and a mother's daily smoking habit were significant risk factors for asthma-like symptoms in both Aboriginal and non-Aboriginal children. In addition, infants and toddlers were at increased risk of asthma-like symptoms in Aboriginal children. In analyses restricted to specific outcomes, a mother's daily smoking habit was a significant risk factor for current wheeze in Aboriginal children and for ever having had asthma in non-Aboriginal children.

CONCLUSIONS: Asthma prevalence appears to be lower in Aboriginal children than in non-Aboriginal children. The association between daily maternal smoking and asthma-like symptoms, which has been mainly reported for children living in urban areas, was observed in Aboriginal and non-Aboriginal children living in northern and remote communities in Canada.

Key Words: Aboriginals; Asthma; Children; Remote area; Risk factors; Smoking

$\Delta$ sthma is one of the most common chronic disorders affectling children and adults, especially in industrialized countries (1). The prevalence of asthma increased in the 1980s and early 1990s; however, recent studies investigating temporal

\section{Prévalence de l'asthme et facteurs de risque de symptômes de type asthme chez les enfants aborigènes et non aborigènes des territoires du Nord canadien}

HISTORIQUE : Peu d'études ont porté sur la prévalence et les facteurs de risque d'asthme chez les enfants d'origine aborigène au Canada. OBJECTIF : Déterminer la prévalence de l'asthme et des symptômes de type asthme, de même que les facteurs de risque à l'égard de ces symptômes chez des enfants aborigènes et non aborigènes qui vivent dans les territoires du Nord canadien.

MÉTHODES : La présente étude repose sur des données relatives à 2404 enfants âgés de 0 à 11 ans qui ont participé à la cohort du Nord de l'Enquête longitudinale nationale sur les enfants et les jeunes (ELNEJ). Un enfant était considéré sujet à des symptômes de type asthme si son dossier portait la moindre mention d'asthme, de crises d'asthme ou de sifflements respiratoires au cours des 12 mois précédents.

RÉSULTATS : Après l'exclusion de 59 enfants faute de données sur leur origine ethnique, 1399 (59,7 \%) se sont révélés d'origine aborigène. La prévalence de l'asthme a été significativement moins grande $(\mathrm{p}<0,05)$ chez les enfants aborigènes $(5,7 \%)$ que chez les enfants non aborigènes $(10,0 \%)$, tandis que la prévalence des sifflements respiratoires a été similaire entre les enfants aborigènes $(15,0 \%)$ et non aborigènes $(14,5 \%)$. Chez les enfants aborigènes, les nourrissons et les tout-petits présentaient une prévalence significativement plus grande de symptômes de type asthme $(30,0 \%)$ que les enfants d'âge préscolaire $(21,5 \%)$ et scolaire $(11,5 \%)$. Lallergie infantile et le tabagisme maternel quotidien ont été des facteurs de risque significatifs à l'égard des symptômes de type asthme, tant chez les enfants aborigènes que non aborigènes. De plus, les nourrissons et les tout-petits d'origine aborigène étaient exposés à un risque plus grand de symptômes de type asthme. Dans des analyses limitées à certains paramètres spécifiques, le tabagisme maternel quotidien s'est révélé être un facteur de risque significatif de problèmes actuels de sifflements respiratoires chez les enfants aborigènes et de tout antécédent d'asthme chez les enfants non aborigènes.

CONCLUSION : La prévalence de l'asthme semble moindre chez les enfants aborigènes que chez les enfants non aborigènes. Le lien entre le tabagisme maternel quotidien et les symptômes de type asthme, principalement signalé chez les enfants des régions urbaines, a été observé chez les enfants aborigènes et non aborigènes vivant dans les communautés nordiques et éloignées du Canada.

${ }^{1}$ Department of Public Health Sciences, School of Public Health; ${ }^{2}$ Department of Emergency Medicine; ${ }^{3}$ Department of Pediatrics; ${ }^{4}$ Alberta Asthma Centre, University of Alberta, Edmonton, Alberta

Correspondence: Dr A Senthilselvan, Department of Public Health Sciences, School of Public Health, 106B Clinical Sciences Building, Edmonton, Alberta T6G 2G3. Telephone 780-492-6505, fax 780-492-0364, e-mail sentil@ualberta.ca 
and asthma-like symptoms. Smoking, housing conditions and overcrowding in Aboriginal communities may also play a role in the prevalence of asthma in Aboriginal children. Only a few studies (3-5) have investigated the prevalence of asthma in the Aboriginal population in Canada. In the 1970s, asthma was reported to be lower in Métis populations living in northern Saskatchewan than among white people living in central Saskatchewan (4), and was reported to be rare in the Canadian Eskimo population (5). In a more recent study in Saskatchewan, the prevalence of asthma, determined from the physician services database, was lower only in children five to 14 years of age among the Registered Indian population (3). The prevalence of exercise-induced bronchospasm has also been reported to be lower in Inuit school children living in northern Quebec (6). In the present study, the prevalence of ever having had asthma, current asthma and current wheeze, and factors associated with asthma-like symptoms in Aboriginal and non-Aboriginal children living in the Northwest Territories, Yukon and Nunavut in Canada are reported.

\section{METHODS}

The National Longitudinal Survey of Children and Youth, North component (NLSCY-North), which was conducted by Statistics Canada in 1994 and 1995 (cycle 1), was used to study asthma prevalence in Aboriginal and non-Aboriginal children living in the Northwest Territories, Yukon and Nunavut (6). During the survey, Nunavut was part of the Northwest Territories, but in anticipation of the division, the survey sample was divided into two regions: the western territory and Nunavut. The western territory is referred to as the Northwest Territories in the present study. The populations from institutions, the Canadian Armed Forces and unorganized areas in the Yukon were excluded from the survey. In addition to these exclusions, populations from remote areas and very small communities in the Northwest Territories and Nunavut were also excluded.

\section{Data collection}

The National Population Health Survey for children and adults 12 years of age and older, and the NLSCY-North for children 11 years of age and younger were conducted simultaneously in the Northwest Territories, Yukon and Nunavut (7). These surveys were integrated to reduce respondent burden. The primary sampling units in the NLSCY-North were households. Randomly selected households with at least one child between 0 and 11 years of age were eligible for inclusion in the survey. The NLSCY-North sampling design for cycle 1 was constructed to guarantee that the sample size was large enough to be stratified into seven age groups: 0 to 11 months, one year, two and three years, four and five years, six and seven years, eight and nine years, 10 and 11 years.

Random samples were selected from the population of private occupied dwellings in the Northwest Territories, Yukon and Nunavut. A maximum of three children were randomly selected from each household. Specially trained persons conducted the interviews by phone or in person. Face-to-face interviews were used for data collection in the Northwest Territories and Nunavut. In the Yukon, face-to-face interviews were used during the first six months of the survey, but was replaced with random digit dialing followed by telephone survey thereafter for the majority of the population.

\section{Questionnaires}

Several questionnaires were administered as part of the survey. The household questionnaire covered basic demographic information for each household member, dwelling conditions and household income. The parent's questionnaire was designed to collect information on age, education, employment, income and household characteristics. The child's questionnaire was designed to collect information on several factors, including the demographics, behaviour, education and health of children selected from the household. One person was assigned as the 'person most knowledgeable' (PMK) about the child. The PMK was asked to complete parent and child questionnaires.

\section{Study sample}

A total of 2404 children participated in cycle 1 of the NLSCYNorth. The Aboriginal ancestry of the children was determined from the response of the PMK to the question, "Do you consider the child to be a First Nation that is Indian, Métis, or Inuit?" After excluding 59 children with missing information on Aboriginal ancestry, 1399 of the 2345 children (59.7\%) who were considered for the analysis were of Aboriginal ancestry.

\section{Definition of asthma, asthma-like symptoms and allergy}

A positive response to the question "Has the child ever had asthma that was diagnosed by a health professional?" was used to determine lifetime prevalence of asthma in children. The presence of current asthma was determined from a positive response to the question "Has he/she had an attack of asthma in the last 12 months?" The presence of current wheeze was determined from a positive response to the question "Has he/she had wheezing in the chest at anytime in the last 12 months?" The presence of asthma-like symptoms was determined from a positive response to any of the previous three questions on ever having had asthma, current asthma or current wheeze, respectively. The question "Does the child have any of the following long-term conditions (lasted or expected to last more than six months) that have been diagnosed by a health professional?" was used to determine the presence of a series of chronic conditions, including allergy. A positive response to the question on 'allergies' was used to define childhood allergy in our study.

\section{Independent factors}

Child-level predictor variables considered in the study included age group, sex, childhood allergy, living with single parent and number of siblings. Parental-level predictors considered in the study were mother's age at the child's birth, education level, allergy, asthma, smoking habit and marital status. Household predictors considered in the study included total income, dwelling ownership, dwelling in need of repairs and place of residence. Mother's allergy was determined from a positive response to the second question in a series of two questions, which were asked in sequence: "Do you have any of the following long-term conditions (lasted or expected to last longer than six months) that have been diagnosed by a health professional: a) food allergies; b) other allergies?" The child's dwelling was considered to be in need of repairs if the dwelling needed minor or major repairs other than regular maintenance (painting, furnace checking, etc). 
TABLE 1

Demographic and individual characteristics of Aboriginal and non-Aboriginal children who participated in the National Longitudinal Survey of Children and Youth-North*

\begin{tabular}{lccc}
\hline Characteristics & $\begin{array}{c}\text { Aboriginal children, } \\
\mathbf{n}(\%)\end{array}$ & $\begin{array}{c}\text { Non-Aboriginal } \\
\text { children, } \mathbf{n}(\%)\end{array}$ & $\mathbf{P}$ \\
\hline $\begin{array}{l}\text { Age group } \\
\text { Infant and toddler }\end{array}$ & $247(17.7)$ & $144(15.2)$ & 0.28 \\
$\quad \begin{array}{l}\text { Preschool-aged } \\
\text { School-aged }\end{array}$ & $372(26.6)$ & $264(27.9)$ & \\
Sex & $780(55.8)$ & $539(56.9)$ & \\
$\quad$ Male & $718(51.3)$ & $487(51.5)$ & 0.94 \\
Female & $681(48.7)$ & $459(48.5)$ & \\
Childhood allergy & $82(6.0)$ & $115(12.3)$ & $<0.0001$ \\
Living with & & $143(15.4)$ & 0.82 \\
One parent & $204(15.8)$ & $789(84.6)$ & \\
$\quad$ Two parents & $1092(84.3)$ & $168(18.1)$ & $<0.0001$ \\
Number of siblings ${ }^{\dagger}$ & & $439(47.3)$ & \\
0 & $145(11.4)$ & $321(34.6)$ & \\
1 & $333(26.3)$ & & \\
$\geq 2$ & $792(62.3)$ & $251(33.4)$ & $<0.0001$ \\
Number of older siblings & & $341(45.3)$ & \\
0 & $267(24.0)$ & $161(21.4)$ & \\
1 & $363(32.6)$ & $483(43.4)$ &
\end{tabular}

${ }^{*}$ Frequencies and proportions were weighted using normalized cross-sectional weights - frequencies do not add up to the total because of missing data; tNumber of siblings includes both older and younger siblings

Statistical analysis

Normalized cross-sectional weights provided by Statistics Canada were applied to adjust for the sampling design and nonresponse of selected households. The prevalence of asthma and asthma-like symptoms in the Aboriginal and nonAboriginal samples were calculated using the normalized crosssectional weights. The generalized estimating equation technique was used in the univariate and multivariate logistic regression analyses to adjust for the correlation among children from the same households (8). Logistic regression analyses were used to determine the significant differences in the distribution of individual and household characteristics between Aboriginal and non-Aboriginal children, and to determine the significant factors associated with asthma and asthma-like symptoms in Aboriginal and non-Aboriginal children. All of the factors that were significant at a 20\% level in the univariate analysis were considered for multivariate analysis. A purposeful selection method was used to determine important factors in the multivariate regression.

\section{RESULTS}

The distribution of demographic and individual characteristics is shown in Table 1. The distribution of age group and sex was similar between Aboriginal and non-Aboriginal children. Significant differences were observed between the two groups in childhood allergy, number of siblings and number of older siblings. The distribution of parental and household characteristics is shown in Table 2. Daily smoking was significantly more prevalent among mothers of Aboriginal children than among mothers of non-Aboriginal children (Table 2). Maternal allergy and asthma were significantly lower in Aboriginal children
TABLE 2

Parental and household characteristics of Aboriginal and non-Aboriginal children who participated in the National Longitudinal Survey of Children and Youth-North*

\begin{tabular}{|c|c|c|c|}
\hline Characteristics & $\begin{array}{c}\text { boriginal children, } \\
n(\%)\end{array}$ & $\begin{array}{l}\text { Non-Aboriginal } \\
\text { children, } \mathrm{n}(\%)\end{array}$ & $\mathbf{P}$ \\
\hline \multicolumn{4}{|l|}{ Mother's age at birth, years } \\
\hline $15-24$ & $490(47.4)$ & $206(23.1)$ & \multirow[t]{3}{*}{$<0.0001$} \\
\hline $25-34$ & $469(45.4)$ & $561(63.2)$ & \\
\hline$\geq 35$ & $74(7.2)$ & $122(13.7)$ & \\
\hline \multicolumn{4}{|l|}{ Mother's education level } \\
\hline Less than secondary & $523(42.8)$ & $69(7.8)$ & \multirow[t]{4}{*}{$<0.0001$} \\
\hline Secondary & $58(4.8)$ & $140(15.7)$ & \\
\hline High school & $419(34.3)$ & $263(30.0)$ & \\
\hline College or higher & $221(18.1)$ & $418(46.9)$ & \\
\hline Mother's allergy & $106(10.9)$ & $221(25.4)$ & $<0.0001$ \\
\hline Mother's asthma & $24(2.5)$ & $82(9.4)$ & $<0.0001$ \\
\hline \multicolumn{4}{|l|}{ Mother's smoking habit } \\
\hline None & $374(28.1)$ & $620(68.5)$ & \multirow[t]{3}{*}{$<0.0001$} \\
\hline Occasional & $184(13.9)$ & $49(5.4)$ & \\
\hline Daily & $770(58.0)$ & $236(26.1)$ & \\
\hline \multicolumn{4}{|l|}{ Mother's marital status } \\
\hline Married & $1172(83.7)$ & $804(85.0)$ & \multirow[t]{3}{*}{$<0.0001$} \\
\hline Single & $128(9.1)$ & $40(4.2)$ & \\
\hline Divorced & $100(7.1)$ & $102(10.8)$ & \\
\hline \multicolumn{4}{|l|}{ Household income, \$ } \\
\hline$<15,000$ & $447(31.9)$ & $34(3.6)$ & \multirow[t]{3}{*}{$<0.0001$} \\
\hline $15,000-40,000$ & $443(31.6)$ & $151(16.0)$ & \\
\hline$\geq 40,000$ & $510(36.4)$ & $761(80.4)$ & \\
\hline Own dwelling & $455(32.8)$ & $593(63.0)$ & $<0.0001$ \\
\hline \multicolumn{4}{|c|}{ Number of rooms in the dwelling } \\
\hline$\leq 2$ & $985(72.2)$ & $804(86.4)$ & \multirow[t]{2}{*}{$<0.0001$} \\
\hline$\geq 3$ & $380(27.8)$ & $127(13.6)$ & \\
\hline Dwelling needing repairs & $570(41.4)$ & $285(30.3)$ & $<0.0001$ \\
\hline \multicolumn{4}{|l|}{ Territory } \\
\hline Northwest Territories & $527(37.7)$ & $412(43.5)$ & \multirow[t]{3}{*}{$<0.0001$} \\
\hline Yukon & $134(9.6)$ & $467(49.4)$ & \\
\hline Nunavut & $738(52.7)$ & $67(7.1)$ & \\
\hline
\end{tabular}

*Frequencies and proportions were weighted using normalized cross-sectional weights - frequencies do not add up to the total because of missing data

TABLE 3

Prevalence of ever asthma, current asthma, wheeze and asthma-like symptoms in Aboriginal and non-Aboriginal children*

\begin{tabular}{lrrrrrrr}
\hline & \multicolumn{4}{c}{ Aboriginal children, \% } & & \multicolumn{3}{c}{ Non-Aboriginal children, \% } \\
\cline { 2 - 5 } \cline { 6 - 8 } Condition & Male & Female & Total & & Male & Female & Total \\
\hline Ever asthma & 4.4 & 7.0 & 5.7 & 11.1 & 8.8 & 10.0 \\
Current asthma & 2.1 & 2.6 & 2.4 & 6.0 & 4.5 & 5.3 \\
Current wheeze & 15.7 & 14.2 & 15.0 & 15.1 & 13.9 & 14.5 \\
Asthma-like symptoms & 17.1 & 17.2 & 17.1 & 18.8 & 17.3 & 18.1 \\
\hline
\end{tabular}

*Prevalence estimates were weighted using normalized cross-sectional weights

than in non-Aboriginal children. Mother's mean age at birth and level of education, in addition to household income, were significantly lower in Aboriginal children. A significantly greater proportion of non-Aboriginal children lived in their 
TABLE 4

Prevalences and ORs of asthma-like symptoms for childhood factors in Aboriginal and non-Aboriginal children*

\begin{tabular}{|c|c|c|c|c|}
\hline \multirow[b]{2}{*}{ Factors } & \multicolumn{2}{|c|}{ Aboriginal children } & \multicolumn{2}{|c|}{ Non-Aboriginal children } \\
\hline & $\begin{array}{l}\text { Asthma-like } \\
\text { symptoms, \% }\end{array}$ & $\%$ OR $(95 \% \mathrm{Cl})$ & $\begin{array}{l}\text { Asthma-like } \\
\text { symptoms, \% }\end{array}$ & $\%$ OR $(95 \% \mathrm{Cl})$ \\
\hline \multicolumn{5}{|l|}{ Age group } \\
\hline Infant and toddle & Ner 30.0 & $3.45(2.38-5.00)$ & 16.6 & $1.08(0.63-1.82)$ \\
\hline Preschool-age & ed 21.5 & $1.97(1.64-2.30)$ & 20.8 & $1.41(1.09-1.73)$ \\
\hline School-aged & 11.5 & 1 & 17.2 & 1 \\
\hline \multicolumn{5}{|l|}{ Sex } \\
\hline Female & 17.2 & $0.99(0.73-1.34)$ & 17.3 & $0.80(0.55-1.16)$ \\
\hline Male & 17.1 & 1 & 18.8 & 1 \\
\hline \multicolumn{5}{|l|}{ Childhood allergy } \\
\hline Yes & 39.7 & $3.29(1.82-5.93)$ & 40.9 & $3.86(2.41-6.11)$ \\
\hline No & 15.9 & 1 & 14.9 & 1 \\
\hline \multicolumn{5}{|l|}{ Living with } \\
\hline One parent & 17.0 & $0.91(0.58-1.45)$ & 19.6 & $0.80(0.48-1.34)$ \\
\hline Two parents & 17.4 & 1 & 17.4 & 1 \\
\hline \multicolumn{5}{|c|}{ Number of siblings } \\
\hline 0 & 22.4 & $1.62(0.99-2.64)$ & 19.2 & $1.11(0.61-2.01)$ \\
\hline 1 & 16.7 & $1.09(0.71-1.70)$ & 17.1 & $0.96(0.57-1.62)$ \\
\hline$\geq 2$ & 15.8 & 1 & 18.2 & 1 \\
\hline
\end{tabular}

${ }^{*}$ Results are from logistic regression analysis for correlated data with normalized cross-sectional weights

own homes, in homes with two or fewer rooms, and in homes needing fewer repairs.

As shown in Table 3, the prevalences of ever having had asthma and current asthma were significantly higher in nonAboriginal than in Aboriginal children $(\mathrm{P}<0.05)$; however, the prevalence of wheeze was similar in the two groups. When these conditions were combined, the prevalence was also similar in the two groups. Female Aboriginal children had a significantly higher prevalence of asthma than male Aboriginal children $(\mathrm{P}<0.05)$; however, this pattern was reversed in male non-Aboriginal children, who had a slightly higher prevalence than female non-Aboriginal children. The prevalence of wheeze among children without health professional-diagnosed asthma was significantly higher $(\mathrm{P}=0.02)$ in Aboriginal children $(12.2 \%)$ than in non-Aboriginal children $(8.9 \%)$.

The prevalence of asthma-like symptoms and the results from the univariate analysis are shown for childhood, parental and household factors in Aboriginal and non-Aboriginal children in Table 4 and Table 5. In Aboriginal children, infants and toddlers, as well as preschool children, had an increased risk of asthma-like symptoms compared with school-aged children (Table 4). In non-Aboriginal children, preschool-aged children had increased risk of asthma-like symptoms compared with school-aged children (Table 4). In both Aboriginal and non-Aboriginal children, childhood allergy was a significant risk factor for asthma-like symptoms. The number of siblings was not significantly associated with asthma-like symptoms in either Aboriginal or non-Aboriginal children. In Aboriginal children, the mother's allergy history and daily smoking habit were significantly associated with asthma-like symptoms (Table 5). Non-Aboriginal children living in the Northwest Territories were at an increased risk of asthma-like symptoms
TABLE 5

Prevalences and ORs of asthma-like symptoms for parental and household factors in Aboriginal and non-Aboriginal children*

\begin{tabular}{|c|c|c|c|c|}
\hline \multirow[b]{2}{*}{ Factors } & \multicolumn{2}{|c|}{ Aboriginal children } & \multicolumn{2}{|c|}{ Non-Aboriginal children } \\
\hline & $\begin{array}{l}\text { hma-like } \\
\text { ptoms, \% }\end{array}$ & OR $(95 \% \mathrm{Cl}) \mathrm{s}$ & $\begin{array}{l}\text { Asthma-like } \\
\text { symptoms, } \%\end{array}$ & $\begin{array}{l}e \\
\% \text { OR }(95 \% \mathrm{Cl})\end{array}$ \\
\hline \multicolumn{5}{|c|}{ Mother's age at birth, years } \\
\hline $15-24$ & 17.6 & $1.15(0.58-2.27)$ & 25.5 & $1.31(0.65-2.66)$ \\
\hline $25-34$ & 19.0 & $1.38(0.71-2.66)$ & 15.4 & $0.86(0.45-1.63)$ \\
\hline$\geq 35$ & 15.2 & 1 & 17.8 & 1 \\
\hline \multicolumn{5}{|c|}{ Mother's education level } \\
\hline \multicolumn{2}{|c|}{ Less than secondary 14.3} & $0.88(0.48-1.60)$ & 23.3 & $1.49(0.71-3.16)$ \\
\hline Secondary & 23.1 & $1.62(0.63-3.82)$ & 21.5 & $1.32(0.70-2.51)$ \\
\hline High school & 18.9 & $1.30(0.71-2.36)$ & 14.1 & $0.77(0.45-1.31)$ \\
\hline College or higher & 15.9 & 1 & 17.5 & 1 \\
\hline \multicolumn{5}{|l|}{ Mother's allergy } \\
\hline Yes & 28.3 & $1.97(1.09-3.56)$ & 20.3 & $1.26(0.75-2.12)$ \\
\hline No & 15.6 & 1 & 16.6 & 1 \\
\hline \multicolumn{5}{|l|}{ Mother's asthma } \\
\hline Yes & 27.1 & $1.70(0.57-5.05)$ & 18.2 & $1.08(0.58-2.03)$ \\
\hline No & 16.7 & 1 & 17.5 & 1 \\
\hline \multicolumn{5}{|c|}{ Mother's smoking habit } \\
\hline Daily & 19.3 & $1.61(1.05-2.50)$ & 21.7 & $1.47(0.95-2.33)$ \\
\hline Occasional & 15.5 & $1.34(0.87-1.81)$ & 21.7 & $1.46(0.21-2.71)$ \\
\hline None & 12.8 & 1 & 16.1 & 1 \\
\hline \multicolumn{5}{|c|}{ Mother's marital status } \\
\hline Married & 17.0 & $1.16(0.59-2.29)$ & 17.8 & $1.04(0.58-1.88)$ \\
\hline Single & 21.6 & $1.63(0.74-3.60)$ & 28.7 & $2.03(0.79-5.31)$ \\
\hline Divorced & 13.8 & 1 & 16.3 & 1 \\
\hline \multicolumn{5}{|l|}{ Household income, \$ } \\
\hline$<15,000$ & 15.2 & $0.98(0.63-1.54)$ & 24.4 & $1.75(0.73-4.18)$ \\
\hline $15,000-40,000$ & 19.8 & $1.27(0.82-1.95)$ & 18.1 & $1.05(0.64-1.73)$ \\
\hline$\geq 40,000$ & 16.5 & 1 & 17.8 & 1 \\
\hline \multicolumn{5}{|l|}{ Own dwelling } \\
\hline Yes & 16.8 & $0.97(0.64-1.45)$ & 16.5 & $0.70(0.45-1.07)$ \\
\hline No & 17.0 & 1 & 20.5 & 1 \\
\hline \multicolumn{5}{|c|}{ Number of rooms in the dwelling } \\
\hline$\geq 3$ & 16.0 & $0.77(0.52-1.13)$ & 18.5 & $1.17(0.66-2.07)$ \\
\hline$\leq 2$ & 19.9 & 1 & 15.8 & 1 \\
\hline \multicolumn{5}{|c|}{ Dwelling needs repair } \\
\hline Yes & 18.7 & $1.21(0.84-1.75)$ & 19.2 & $1.11(0.70-1.72)$ \\
\hline No & 15.9 & 1 & 17.7 & 1 \\
\hline \multicolumn{5}{|l|}{ Territory } \\
\hline Yukon & 20.0 & $1.08(0.71-1.67)$ & 15.9 & $1.38(0.56-3.39)$ \\
\hline Northwest Territorie & es 13.4 & $0.63(0.41-1.03)$ & 21.3 & $1.92(1.36-4.96)$ \\
\hline Nunavut & 19.3 & 1 & 12.9 & 1 \\
\hline
\end{tabular}

${ }^{*}$ Results are from logistic regression analysis for correlated data with normalized cross-sectional weights

in comparison with the non-Aboriginal children living in Nunavut (Table 5).

As shown in Table 6, statistically significant factors from the multivariate analysis in Aboriginal children were age group (infant/toddler versus school-aged: OR 3.72, 95\% CI 2.51 to 5.52; preschool-aged versus school-aged: OR 1.93, 95\% CI 1.34 to 2.77 ), childhood allergy (OR 2.91, 95\% CI 1.55 to 5.49 ) and 
the mother's smoking habit (daily versus none: OR 1.88, 95\% CI 1.18 to 3.01). In non-Aboriginal children, factors associated with asthma-like symptoms were childhood allergy (OR 3.77, 95\% CI 2.30 to 6.19) and the mother's smoking habit (daily versus none: OR 1.66, 95\% CI 1.05 to 2.63).

In analyses restricted to wheeze outcome, after controlling for age group, sex and childhood allergy, the mother's daily smoking habit was a significant risk factor for current wheeze in Aboriginal children (OR 2.55, 95\% CI 1.45 to 4.48) but not in non-Aboriginal children (OR 1.21, 95\% CI 0.69 to 2.14). In analyses restricted to asthma outcome, after controlling for age group, sex and childhood allergy, mother's daily smoking habit was a significant risk factor for ever having had asthma in non-Aboriginal children (OR 1.96, 95\% CI 1.05 to 3.66) but not in Aboriginal children (OR 0.87, 95\% CI 0.45 to 1.66).

\section{DISCUSSION}

Using a large population-based database, the present study found that Aboriginal children had a significantly lower prevalence of health professional-diagnosed asthma than nonAboriginal children. However, the prevalence of asthma-like symptoms was similar in Aboriginal and non-Aboriginal children. In addition, the prevalence of asthma in non-Aboriginal children $(10 \%)$ was similar to that reported in Canadian children (12.2\%) (9). In our study, the overall prevalence of asthma was $5.7 \%$ in Aboriginal children. The lower prevalence of health care professional-diagnosed asthma among Aboriginal children might have been related to differences in access to health care services between Aboriginal and non-Aboriginal populations. The higher prevalence of wheeze among Aboriginal children without an asthma diagnosis indicated that these Aboriginal children might have had reduced access to health care services, and might not have had an opportunity to meet with a health care professional and thus receive a diagnosis of asthma. In a study based on the 1991 Aboriginal Peoples Survey and the 1991 General Social Survey, Aboriginals were much less likely to use physician services than the total Canadian population, even though both populations ranked their health similarly (10).

In the 1970s, asthma was a rare condition in the Eskimo population (5). In Saskatchewan, the prevalence of asthma, determined from the physician services database, was higher in children between 0 and four years of age and lower in children five to 14 years of age in the Registered Indian population in comparison with other Saskatchewan populations (3). In our study, the sample size was too small to investigate the asthma prevalence in children younger than four years of age. In another study, the prevalence of exercise-induced bronchospasm in boys and girls among Inuit school children living in northern Quebec was lower than that observed among a group of urban school children in Montreal, Quebec (6). Hospitalization rates for asthma in Aboriginal and Torres Strait Islander children aged one to nine years were also reported to be significantly lower than in the rest of the population in Australia (11). In a study of 287,329 children between 0 and 14 years of age in China, asthma prevalence was found to be $1.5 \%$ (12), which was much lower than the corresponding asthma prevalence in developed countries, including Canada. In our study, the prevalence of asthma was higher in non-Aboriginal boys than non-Aboriginal girls, but this was reversed in Aboriginal children. However, when ever having had asthma, current asthma and current wheeze were combined

\section{TABLE 6}

Factors associated with asthma-like symptoms in the multivariate logistic regression analysis in Aboriginal and non-Aboriginal children*

\begin{tabular}{|c|c|c|c|c|}
\hline \multirow[b]{2}{*}{ Factors } & \multicolumn{2}{|c|}{ Aboriginal children } & \multicolumn{2}{|c|}{ Non-Aboriginal children } \\
\hline & OR $(95 \% \mathrm{Cl})$ & $\mathbf{P}$ & OR $(95 \% \mathrm{Cl})$ & $\mathbf{P}$ \\
\hline \multicolumn{5}{|l|}{ Age group } \\
\hline Infant and toddler & $3.72(2.51-5.52)$ & $<0.0001$ & $1.15(0.64-2.06)$ & 0.64 \\
\hline Preschool-aged & $1.93(1.34-2.77)$ & 0.0004 & $1.41(0.96-2.09)$ & 0.08 \\
\hline School-aged & 1 & & 1 & \\
\hline \multicolumn{5}{|l|}{ Sex } \\
\hline Female & $0.91(0.65-1.26)$ & 0.57 & $0.86(0.58-1.27)$ & 0.44 \\
\hline Male & 1 & & 1 & \\
\hline \multicolumn{5}{|l|}{ Childhood allergy } \\
\hline Yes & $2.91(1.55-5.49)$ & 0.0009 & $3.77(2.30-6.19)$ & $<0.0001$ \\
\hline No & 1 & & 1 & \\
\hline \multicolumn{5}{|c|}{ Mother's smoking habit } \\
\hline Daily & $1.88(1.18-3.01)$ & 0.008 & $1.66(1.05-2.63)$ & 0.03 \\
\hline Occasionally & $1.58(0.86-2.90)$ & 0.14 & $1.17(0.38-3.64)$ & 0.79 \\
\hline None & 1 & & 1 & \\
\hline
\end{tabular}

${ }^{*}$ Results from logistic regression analysis for correlated data with normalized cross-sectional weights

into asthma-like symptoms, boys were at reduced risk of asthmalike symptoms than girls in both Aboriginal and nonAboriginal children. Aboriginal women appear to receive diagnoses of diseases from health care professionals more often than Aboriginal men. In a study examining the sex differences in Canadian Aboriginal individuals admitted to an inpatient, hospital-based substance abuse detoxification program, women received a greater proportion of cocaine or opiate detoxification diagnoses than men, even though alcohol was the most frequent primary drug of detoxification for both sexes (13). Several studies have reported that boys have a higher prevalence of asthma than girls $(3,14,15)$. In the Avon Longitudinal Study of Parents and Children (ALSPAC) - a birth cohort study conducted in the United Kingdom - maternal reports of child wheezing that persisted from birth to six months of age were significantly more common in boys than girls in the first three-and-a-half years of their lives (14). In Canada, sex differences in the prevalence of asthma have also been reported among Aboriginal populations in Saskatchewan (3). Boys are at greater risk of developing asthma than girls, approximately until the age of puberty. The reasons for the sex differences in asthma morbidity are not well understood. However, in a review article (15), differences in hormonal changes between boys and girls at puberty, in addition to smaller airways relative to lung volume in boys, were discussed as possible pathophysiological mechanisms for the sex differences in the prevalence of asthma (15).

In our study, the prevalence of asthma-like symptoms in infants and toddlers was higher than that in older age groups of Aboriginal children. These differences may be related to exposure to second-hand smoke at home. In a 1995 survey of the Aboriginal population, the smoking rate was 57\%, which was twofold that of people in the general Canadian population (27\%). In Aboriginals, the highest smoking rate was in Inuit (72\%), followed by $57 \%$ in Métis and $56 \%$ in First Nations people (16). In a 1997 survey of the Aboriginal population, adults reported that they started smoking at approximately 
16 years of age, with some as early as 11 years of age, and a few as young as eight years of age (17). In a study comparing American Indian and Alaskan Native children using Washington State (United States) hospitalization data for 1987 to 1999 (18), there were no significant differences in asthma hospitalization rates in children between one and five years of age. Conversely, Indian and Alaskan Native children younger than one year of age had two- to threefold higher rates of asthma hospitalization in comparison with overall asthma hospitalization rates in Washington State (18).

In our study, the prevalence of parental reports of childhood allergy in Aboriginal children was 5.9\%, which was comparable with those reported in children aged six to 13 years in four Inuit communities in northern Quebec (diagnosis was based on skin prick testing and varied between $2.1 \%$ and $7.1 \%$ ) (6). Childhood allergy showed a significant association with prevalence of asthma-like symptoms in both Aboriginal and nonAboriginal children. A study of twins conducted in Finland found that among asthmatic children with at least one asthmatic parent, genetic factors explained $87 \%$ of the variation in susceptibility to asthma $(19,20)$. Childhood allergy is another important factor associated with asthma, which has been reported in many studies $(21,22)$. Childhood allergy history has also been reported to be strongly associated with asthma among children from ethnic minority groups, such as AfricanAmerican and Mexican-American groups $(23,24)$. In a study of 4164 children aged six to 16 years who participated in allergen testing in the Third National Health and Nutrition Examination Survey conducted in the United States from 1988 to 1994, African-American and Mexican-American children were substantially more likely to be sensitized to allergens than Caucasian children (23). Childhood allergy has also been reported to be a significant risk factor for asthma in countries where the prevalence of asthma is very low. In a study of 10,902 school children aged nine to 11 years in China, atopic sensitization, determined by skin-prick tests, was significantly associated with asthma (24).

In our study, the mother's daily smoking habit was a significant factor associated with the prevalence of asthma-like symptoms in both Aboriginal and non-Aboriginal children. In analyses restricted to specific outcomes, the mother's daily smoking habit was a significant risk factor for current wheeze in Aboriginal children and for ever having had asthma in non-Aboriginal children. Several studies have shown that parental cigarette smoking, especially maternal smoking, is a significant risk factor for asthma and wheeze in children. Cotinine levels in saliva and the child's smoking habit were not significantly associated with exercise-induced bronchospasm in a study of Inuit school children living in northern Quebec (6). Maternal smoking was associated with a twofold higher incidence of transient and persistent wheezing only among the children aged 0 to three years; maternal smoking was less associated with the incidence of late-onset wheezing (25). A study of children (six to seven years of age) and adolescents (13 to 14 years of age) in Italy showed that parental smoking was associated with current asthma and wheeze in children, and maternal smoking during pregnancy was a significant risk factor for current asthma symptoms, including wheezing in children (26). In a study from southern California, United States, investigating the effect of maternal smoking during pregnancy and childhood environmental smoke in 5762 children aged 10 years or younger, in utero exposure to maternal smoking without postnatal exposure to environmental smoke was associated with an increased prevalence of physician-diagnosed asthma, wheeze-related symptoms, asthma severity and emergency room visits (27). In the present study, current and previous environmental smoke exposure was associated with wheeze-related symptoms but not with asthma prevalence. In a birth cohort study of 4089 infants conducted in Sweden, maternal smoking during pregnancy was associated with recurrent wheezing and physician-diagnosed asthma until two years of age, but exposure to environmental smoke was not associated with these outcomes (28). There have been extensive studies of the effects of tobacco smoke exposure on childhood asthma, particularly when the mother is a smoker (29-32). There is also evidence showing that tobacco smoke exposure can increase asthma severity in both children and adults $(33,34)$.

There are several limitations that need to be considered in the present study. The survey was a general health survey, and did not specifically focus on asthma and/or wheeze. Questions related to episodes of chest tightness, nocturnal shortness of breath and cough were not included in the questionnaire. Information on several risk factors, including exposure to animals, as well as types of heating and cooking apparatus, were not available.

In the present study, reports from the PMK on physiciandiagnosed asthma, current asthma and current wheeze were used to determine asthma prevalence. Bootstrap weights were not available to obtain efficient estimates in the statistical analysis. Sample sizes of both Aboriginal and non-Aboriginal children may not have been adequate to determine the statistical significance of factors that had weak associations with asthma-like symptoms.

\section{CONCLUSIONS}

Asthma prevalence appears to be lower in Aboriginal children than in non-Aboriginal children in remote northern communities of Canada. The association between maternal daily smoking and asthma-like symptoms, which has been mainly reported for children living in urban areas, was observed in Aboriginal and non-Aboriginal children living in the northern and remote communities of Canada.

DISCLAIMER: The research and analysis in this study are based on data from Statistics Canada, and the opinions expressed herein do not represent the views of Statistics Canada.

FUNDING: This study was supported by a grant from the Canadian Institutes for Health Research (grant number 62909).

\section{REFERENCES}

1. The International Study of Asthma and Allergies in Childhood (ISAAC). Steering Committee. Worldwide variation in prevalence of symptoms of asthma, allergic rhinoconjunctivitis, and atopic eczema: ISAAC. Lancet 1998;351:1225-32.

2. Lawson JA, Senthilselvan A. Asthma epidemiology: Has the crisis passed? Curr Opin Pulm Med 2005;11:79-84.

3. Senthilselvan A, Lawson J, Rennie DC, Dosman JA. Stabilization of an increasing trend in physician-diagnosed asthma prevalence in Saskatchewan, 1991 to 1998 . Chest 2003;124:438-48.

4. Gerrard JW, Geddes CA, Reggin PL, Gerrard CD, Horne S. Serum IgE levels in white and metis communities in Saskatchewan. Ann Allergy 1976;37:91-100.

5. Herxheimer H, Schaefer O. Asthma in Canadian Eskimos. N Engl J Med 1974;291:1419. (Lett) 
6. Hemmelgarn B, Ernst P. Airway function among Inuit primary school children in far northern Quebec. Am J Respir Crit Care Med 1997;156:1870-5

7. Statistics Canada. Indicators based on Statistics Canada (STC) surveys. <http://www.statcan.ca/> (Version current at March 14, 2008).

8. Statistics Canada. Data sets and research tools. $<$ http://www.statcan .ca/english/rdc/whatdata.htm $>$ (Version current at March 14, 2008).

9. Public Health Agency of Canada. Measuring up: A health surveillance update on Canadian children and youth.

$<$ http://www.phac-aspc.gc.ca/publicat/meas-haut/mu_r_e.html > (Version current at March 14, 2008).

10. Newbold KB. Aboriginal physician use in Canada: Location, orientation and identity. Health Econ 1997;6:197-207.

11. Whybourne A, Lesnikowski C, Ruben A, Walker A. Low rates of hospitalization for asthma among Aboriginal children compared to non-Aboriginal children of the top end of the northern territory. J Paediatr Child Health 1999;35:438-41.

12. Chen YZ. Comparative analysis of the state of asthma prevalence in children from two nation-wide surveys in 1990 and 2000 year. Zhonghua Yi Xue Ke Xue Za Zhi 2004;27:112-6.

13. Callaghan RC, Cull R, Vettese LC, Taylor L. A gendered analysis of Canadian Aboriginal individuals admitted to inpatient substance abuse detoxification: A three-year medical chart review. Am J Addict 2006; 15:380-6.

14. Sherriff A, Peters TJ, Henderson J, Strachan D; Avon Longitudinal Study of Parents and Children. Risk factor associations with wheezing patterns in children followed longitudinally from birth to 3(1/2) years. Int J Epidemiol 2001;30:1473-84.

15. Bjornson CL, Mitchell I. Gender differences in asthma in childhood and adolescence. J Gend Specif Med 2000;3:57-61.

16. Godel J, Chatel N. Tobacco use among Aboriginal children and youth. Paediatr Child Health 1999;4:277-81.

17. First Nations and Inuit Health Surveys, 1997: A Synthesis of the National and Regional Reports. Ottawa: National Aboriginal Health Organization, 2004.

18. Liu LL, Stout JW, Sullivan M, Solet D, Shay DK, Grossman DC. Asthma and bronchiolitis hospitalizations among American Indian children. Arch Pediatr Adolesc Med 2000;154:991-6.

19. Räsänen M, Kaprio J, Laitinen T, Winter T, Koskenvuo M, Laitinen LA. Perinatal risk factors for asthma in Finnish adolescent twins. Thorax 2000;55:25-31.

20. Laitinen T, Räsänen M, Kaprio J, Koskenvuo M, Laitinen LA Importance of genetic factors in adolescent asthma: A populationbased twin-family study. Am J Respir Crit Care Med 1998;157:1073-8.

21. Nickel R, Lau S, Niggemann B, et al; MAS Group. Messages from the German Multicentre Allergy Study. Pediatr Allergy Immunol 2002;13(Suppl 15):7-10.
22. Illi S, von Mutius E, Lau S, et al; Multicenter Allergy Study Group. The natural course of atopic dermatitis from birth to age 7 years and the association with asthma. J Allergy Clin Immunol 2004;113:925-31

23. Stevenson LA, Gergen PJ, Hoover DR, Rosenstreich D, Mannino DM, Matte TD. Sociodemographic correlates of indoor allergen sensitivity among United States children. J Allergy Clin Immunol 2001;108:747-52.

24. Wong GW, Hui DS, Chan HH, et al. Prevalence of respiratory and atopic disorders in Chinese schoolchildren. Clin Exp Allergy 2001:31:1225-31.

25. Martinez FD, Wright AL, Taussig LM, Holberg CJ, Halonen M, Morgan WJ. Asthma and wheezing in the first six years of life. The Group Health Medical Associates. N Engl J Med $1995 ; 332: 133-8$

26. Agabiti N, Mallone S, Forastiere F, et al. The impact of parental smoking on asthma and wheezing. SIDRIA Collaborative Group. Studi Italiani sui Disturbi Respiratori nell'Infanzia e l'Ambiente. Epidemiology 1999;10:692-8.

27. Gilliland FD, Li YF, Peters JM. Effects of maternal smoking during pregnancy and environmental tobacco smoke on asthma and wheezing in children. Am J Respir Crit Care Med 2001;163:429-36.

28. Lannerö E, Wickman M, Pershagen G, Nordvall L. Maternal smoking during pregnancy increases the risk of recurrent wheezing during the first years of life (BAMSE). Respir Res 2006;7:3.

29. United States Environmental Protection Agency. Respiratory Health Effects of Passive Smoking: Lung Cancer and Other Disorders. Washington, District of Columbia: Office of Research and Development, Office of Health and Environmental Assessment, 1992.

30. Department of Health and Human Services. The Health Consequences of Involuntary Smoking: A Report of the Surgeon General. Washington, District of Columbia: United States Public Health Service, 1986.

31. National Research Council. Environmental Tobacco Smoke: Measuring Exposures and Assessing Health Effects. Washington, District of Columbia: National Academy Press, 1986.

32. Samet JM, Lange P. Longitudinal studies of active and passive smoking. Am J Respir Crit Care Med 1996;154:S257-65.

33. Mannino DM, Homa DM, Redd SC. Involuntary smoking and asthma severity in children: Data from the Third National Health and Nutrition Examination Survey. Chest 2002;122:409-15.

34. Althuis MD, Sexton M, Prybylski D. Cigarette smoking and asthma symptom severity among adult asthmatics. J Asthma 1999;36:257-64. 


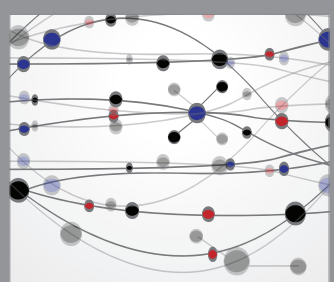

The Scientific World Journal
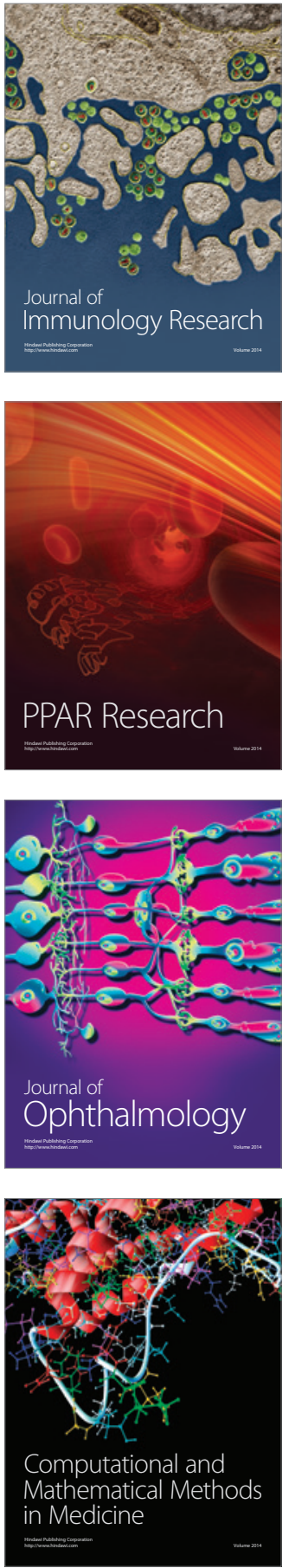

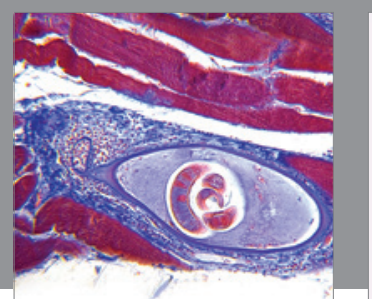

Gastroenterology Research and Practice

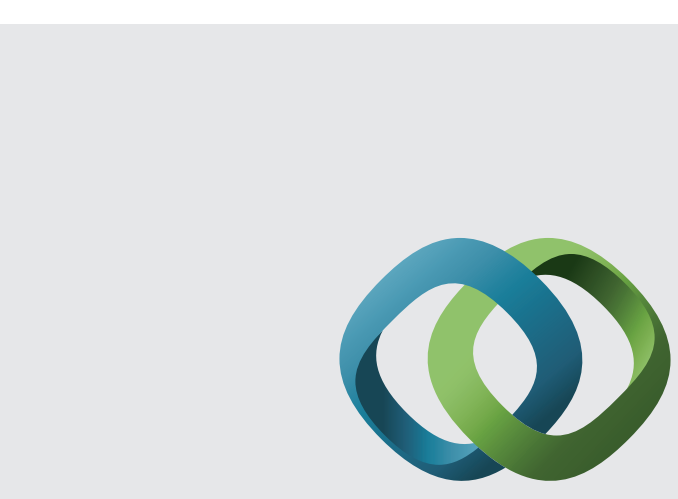

\section{Hindawi}

Submit your manuscripts at

http://www.hindawi.com
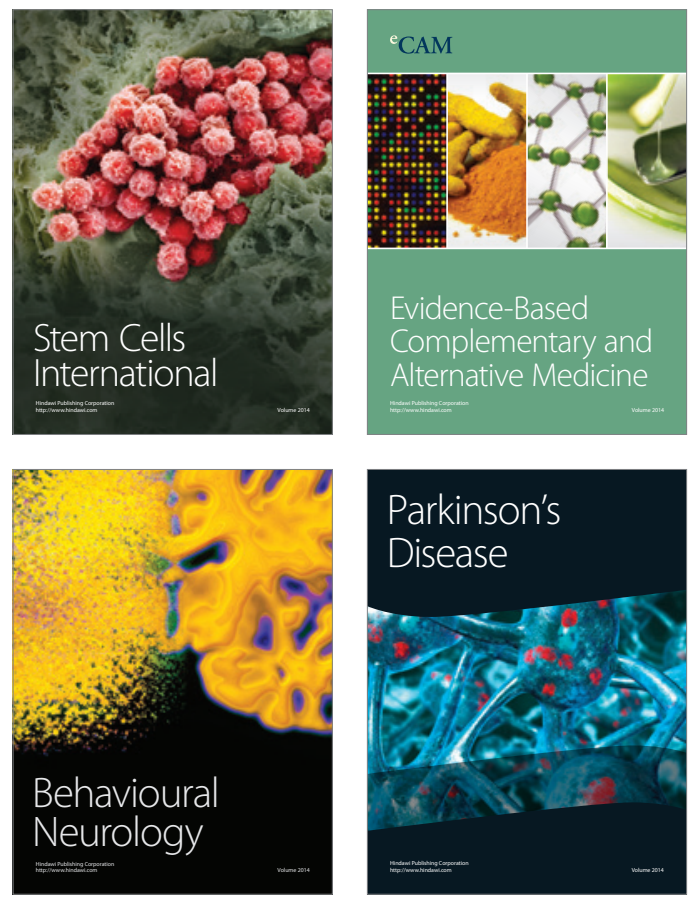
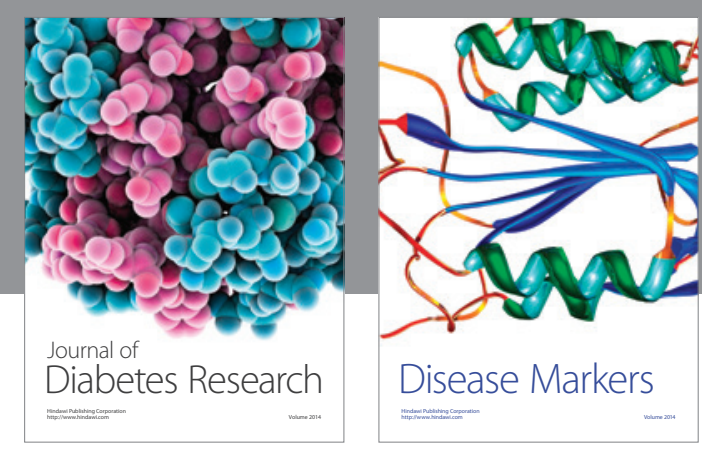

Disease Markers
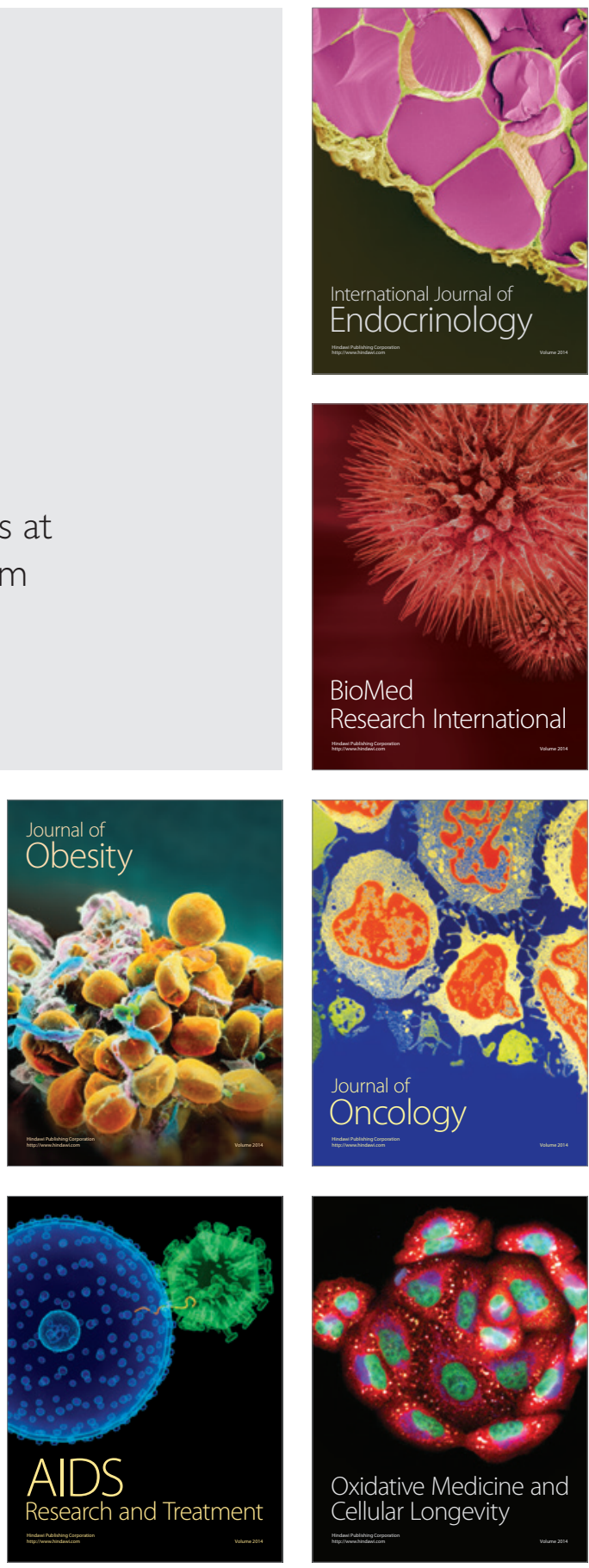